\title{
The Positive Impact of Donor Bone Marrow Cells Transplantation into Immunoprivileged Compartments on the Survival of Vascularized Skin Allografts
}

\author{
Arkadiusz Jundziłł ${ }^{1,2,4} \cdot$ Aleksandra Klimczak ${ }^{3,4} \cdot$ Erhan Sonmez $^{4,5} \cdot$ Grzegorz Brzezicki $^{4,6} \cdot$ Maria Siemionow $^{4,7,8}$
}

Received: 7 April 2021 / Accepted: 2 August 2021 / Published online: 11 October 2021

(c) The Author(s) 2021

\begin{abstract}
Using the vascularized skin allograft (VSA) model, we compared the tolerogenic effects of different allogeneic bone marrow transplantation (BMT) delivery routes into immunoprivileged compartments under a 7-day protocol immunosuppressive therapy. Twenty-eight fully MHC mismatched VSA transplants were performed between ACI (RT1 $1^{\mathrm{a}}$ ) donors and Lewis $\left(\mathrm{RT} 1^{1}\right.$ ) recipients in four groups of seven animals each, under a 7-day protocol of alfa/beta TCRmAb/CsA (alpha/beta-TCR monoclonal antibodies/Cyclosporine A therapy). Donor bone marrow cells (BMC) $(100 \times 106$ cells) were injected into three different immunoprivileged compartments: Group 1: Control, without cellular supportive therapy, Group 2: Intracapsular BMT, Group 3: Intragonadal BMT, Group 4: Intrathecal BMT. In Group 2, BMC were transplanted under the kidney capsule. In Group 3, BMC were transplanted into the right testis between tunica albuginea and seminiferous tubules, and in Group 4, cells were injected intrathecally. The assessment included: skin evaluation for signs and grade of rejection and immunohistochemistry for donor cells engraftment into host lymphoid compartments. Donor-specific chimerism for MHC class I $\left(\mathrm{RT}^{\mathrm{a}}\right)$ antigens and the presence of $\mathrm{CD} 4^{+} / \mathrm{CD} 25^{+} \mathrm{T}$ cells were assessed in the peripheral blood of recipients. The most extended allograft survival, 50-78 days, was observed in Group 4 after intrathecal BMT. The T cells $\mathrm{CD} 4{ }^{+} / \mathrm{CD} 25^{+}$ in the peripheral blood were higher after intrathecal BMC injection than other experimental groups at each post-transplant time point. Transplantation of BMC into immunoprivileged compartments delayed rejection of fully mismatched VSA and induction of robust, donor-specific chimerism.
\end{abstract}

Keywords Bone marrow cells transplantation · Cells supportive therapy · Immunoprivileged compartments · Vascularized composite allotransplantation · Groin flap

\section{Introduction}

Vascularized composite allografts (VCA) represent a robust model for restoration for significant skin defects (Petit et al. 2003). However, skin and muscle components' high antigenicity demands lifelong immunosuppression to prevent

Maria Siemionow

siemiom@uic.edu; siemiom@hotmail.com

1 Department of Regenerative Medicine, Cell and Tissue Bank, Ludwik Rydygier Medical College, Nicolaus Copernicus University in Torun, Bydgoszcz, Poland

2 Department of Plastic, Reconstructive and Aesthetic Surgery, Collegium Medicum in Bydgoszcz, Nicolaus Copernicus University in Toruń, Bydgoszcz, Poland

3 Hirszfeld Institute of Immunology and Experimental Therapy, Polish Academy of Sciences, Wrocław, Poland rejection and extend allograft survival (Siemionow 2020). The multiple side effects of lifelong immunosuppression supported the studies on the discovery of new toleranceinducing strategies. Induction of donor-specific tolerance is a primary goal in VCA transplantation research to be applicable in the cases of non-life-threatening procedures

4 Department of Plastic Surgery, Cleveland Clinic, Cleveland, $\mathrm{OH}$, USA

5 Katip Çelebi Üniversity, Atatürk Training Hospital, Plastic and Reconstructive Surgery Clinic, İzmir, Turkey

6 Department of Neurosurgery, Virginia Commonwealth University, Richmond, VA, USA

7 Department of Orthopaedics, The University of Illinois at Chicago, Chicago, IL, USA

8 Department of Surgery, University of Medical Sciences, Poznan, Poland 
(Cendales et al. 2008; Gordon et al. 2009). Various strategies to induce VCA tolerance have been discovered and tested (Siemionow and Nasir 2007). Allogeneic bone marrow cell (BMC) transplantation is a well-known option for the induction of donor-specific chimerism and prevention of allograft rejection in the experimental models (Asari et al. 2011; Leonard et al. 2013b; Safinia et al. 2013; Siemionow and Nasir 2008). However, the effects of cell-based therapies the following transplantation into immunoprivileged compartments has not been yet well-established as a promising new approach for tolerance induction strategy. The immunoprivileged sites are more suitable for cellular transplants and offer complete or partial protection from all rejection without the need for life-long immunosuppressive therapy (Stevenson et al. 1997). Previously, intrathecal, intracapsular space, and intermembrane testis spaces have been suggested as immunoprivileged regions able protecting allogeneic cells from rejection (Fijak et al. 2011; Muldoon et al. 2013; Robertson et al. 2007). However, limited investigations have been conducted evaluating the implications of regional cell transplantation on the induction of donor chimerism. Moreover, there is limited number of studies in the literature on the impact of BMC transplantation into the immunoprivileged regions and its relation with the allograft survival or rejection. Thus, we introduced our well-established VCA transplant model to investigate a new tolerogenic approach of different routes of bone marrow transplantation (BMT) into immunoprivileged compartments of vascular skin allograft recipients.

\section{Materials and Methods}

\section{Animals and Animal Care}

Cleveland Clinic's Institutional Animal Care and Use Committee (Cleveland, OH, USA), accredited by the American Association for the Accreditation of Laboratory Animal Care (\#2012-0841), approved this study. All animals received humane care in compliance with the "Principles of Laboratory Animal Care" formulated by the National Society for Medical Research and the "Guide for the Care, and Use of Laboratory Animal Resources" published by the US National Institutes of Health (Guide for the care and use of laboratory animal resources 2011). Animals were caged at room temperature on a 12-h light/dark cycle. Standard laboratory food and water were available ad libitum. Animals were housed in a barrier animal facility and cared for according to specific National Institutes of Health animal care guidelines. Inbred 8-10 week-old Lewis (LEW, RT1 ${ }^{1}$ ) rats weighing between 200 and $225 \mathrm{~g}$ and 4-6 week-old ACI $\left(\mathrm{RT}^{1}{ }^{\mathrm{a}}\right)$ rats weighing between 100 and $125 \mathrm{~g}$ were purchased from Harlan Sprague Dawley (Indianapolis, IN) fully MHC mismatched. In all allotransplantations, LEW rats were recipients, and ACI rats served as allograft donors. Surgical procedures were performed under an anesthesia cocktail of ketamine $(30 \mathrm{mg} / \mathrm{kg})$, xylazine $(6 \mathrm{mg} / \mathrm{kg})$, and acepromazine $(1 \mathrm{mg} / \mathrm{kg})$. Additional doses were given if necessary. Postoperative pain was controlled by applying non-steroidal anti-inflammatory drugs, paracetamol, and opioids (McPherson 1980).

\section{Experimental Groups}

Twenty-eight fully MHC mismatched vascularized skin allograft (VSA) transplants were performed between ACI $\left(\mathrm{RT}^{\mathrm{a}}{ }^{\mathrm{a}}\right)$ donors and Lewis $\left(\mathrm{RT} 1^{1}\right)$ recipients in four groups of seven animals each, under a 7-day protocol of alfa/beta TCR/ CsA therapy (Siemionow et al. 2002, 2003). VSA transplants were supported by donor $\mathrm{ACI}\left(\mathrm{RT}^{\mathrm{a}}\right)$ BMT in the amount of $100 \times 10^{6}$ cells transplanted into three different immunoprivileged compartments; Group 1 served as allograft rejection control without BMC. VCA therapy groups received bone marrow cells $\left(100 \times 10^{6}\right)$ transplantation into three different immunoprivileged compartments: the intracapsular (Group 2), the intragonadal (Group 3), and the intrathecal space (Group 4).

\section{Surgical Procedure}

There was a two-stage operating procedure:

\section{Vascular skin allograft transplantation procedure}

The surgical procedure of skin allograft transplantation was accomplished in two stages: harvesting the flap and recipient preparation and allograft transplantation (Fig. 1). The donor VSA was approximately four by $4 \mathrm{~cm}$. The border of the VSA was extended from $5 \mathrm{~cm}$ below the xiphoid process and the last rib (half the length of the symphysis pubis) to the inguinal ligament and between the right mid-axillary line and midline. Following the skin island's incision, the right VSA was elevated over the anterior abdominal wall muscle. Superficial epigastric vessels were dissected to their origins at the femoral artery (Siemionow and Kulahci 2007). Femoral vessels were ligated proximally near the inguinal ligament and distally from the region of epigastric vessel origins and divided during flap elevation (Nasir et al. 2008) (Fig. 1A). In the recipient rat Lewis $\left(\mathrm{RT} 1^{1}\right)$, the suitable femoral vessels were exposed and dissected proximally up to the inguinal ligament and distally down to the branching from the superficial epigastric vessels. In the recipient rat the groin skin was resected to make the defect proportional to the donor flap size (Fig. 1B). The flap ACI (RT1 $1^{\mathrm{a}}$ ) pedicle was anastomosed with the femoral artery. The recipient's vein using standard end-to-end 10-0 nylon interrupted sutures under operating-microscope magnification with 

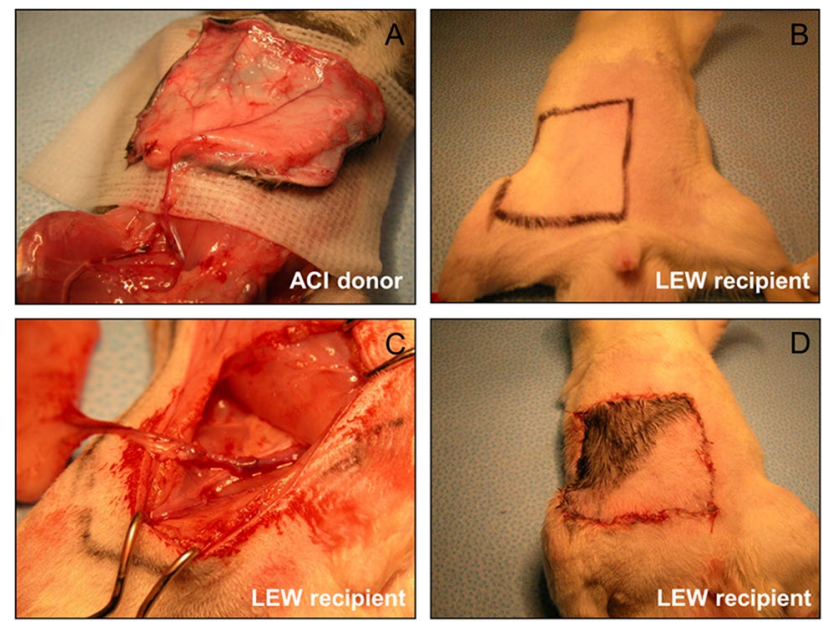

Fig. 1 Transplantation procedure of VSA groin flap transplantation. Explanation in a text conventional microsurgical techniques (Fig. 1C). The graft's skin component was sutured to the edges of the previously created skin defect in the recipient groin region with absorbable sutures 4-0 (Fig. 1D) (Vicryl, Ethicon, Inc.).

\section{Bone marrow cells (BMC) transplantation into immunoprivileged compartments (Fig. 2)}

Group 2: Intracapsular BMC transplantation (Fig. 2A, B) After anesthesia has taken effect, two saline-dampened cottontipped applicators are used to maneuver through a small incision through the skin, muscle, and peritoneum of the animal's left backside expose the left kidney outside of the body. Employing a slight pressure to both sides of the incision, we rolled the kidney out of the abdominal cavity. The kidney capsule was moistened by applying saline with a cotton-tipped swab. Then through the lower pole of the kidney, not involving the renal pelvis, $0.06 \mathrm{ml}$ of bone marrow
Fig. 2 Different routes of bone marrow cells (BMC) transplantation $\left(100 \times 10^{6}\right)$. A, B Group 2: Intracapsular BMC transplantation; C, D Group 3: Intragonadal BMC transplantation; $\mathbf{E}$, F Group 4: Intrathecal BMC transplantation
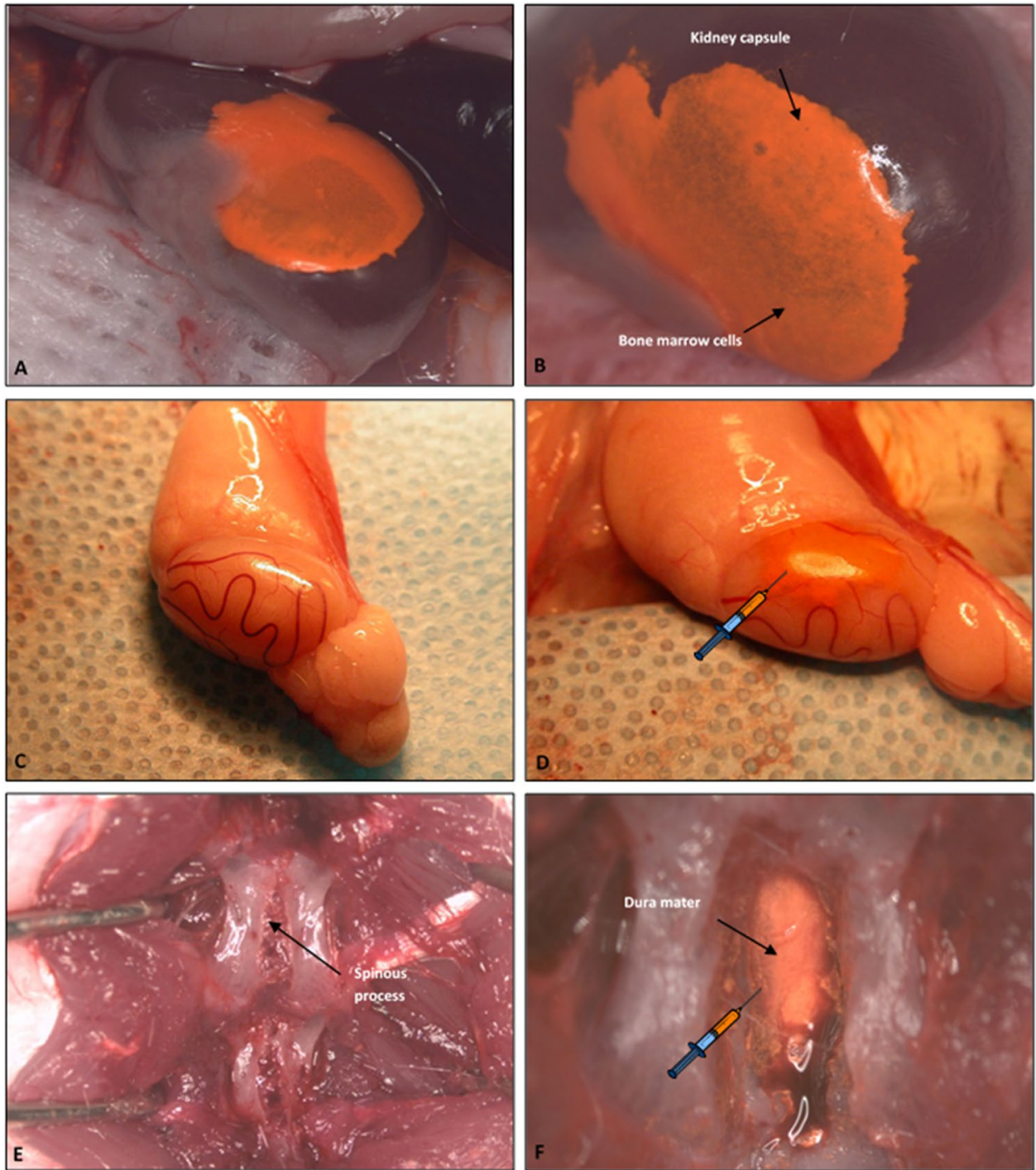
cell suspension was injected under the upper kidney capsule using a $0.5 \mathrm{ml}$ syringe with a $31 \mathrm{G}$ needle (Robertson et al. 2007; Toledo-Pereyraet al. 1984). To stop the bleeding, a dry cotton-tipped swab or cauterization with low heat was used. Then, the kidney was pre-moistened with sterile saline. The kidney was gently placed back into the peritoneum before closing the abdominal wall. The muscle layer and the skin were sewed with running 4-0 absorbable sutures.

Group 3: Intragonadal BMC transplantation (Fig. 2C, D) The animal was placed in the lateral supine position. Then the scrotal and inguinal regions were trimmed and swabbed with a Povidone-Iodine solution before the surgery. A linear incision was made lateral to the median raphe on the right side. The right testis enclosed in the parietal vaginal tunic was gently exposed using a cotton-tipped stick. The small incision helped to keep the testicle raised and exposed. The testicle was swabbed with normal saline preventing tunica albuginea rupture. Using a $0.5 \mathrm{ml}$ syringe with a $31 \mathrm{G}$ needle, the $0.06 \mathrm{ml}$ of bone marrow cell suspension was injected between the tunica albuginea and convoluted seminiferous tubules (Fijak and Meinhardt 2006; Schlatt et al. 1999). After the cell transplantation, the testicle was placed back in the scrotum. The scrotum skin was closed with a running stitch using $5-0$ running silk sutures and a C-6 19 mm needle.

Group 4: Intrathecal BMC Transplantation (Fig. 2E, F) The rat was placed in a prone position, and a midline skin incision was performed approximately $2-3 \mathrm{~cm}$ above vertebrae L4-L5. The paraspinous muscles were detached using a thermocautery technique. Using the Love-Kerrison punch, the laminotomy was conducted. Particular attention was paid to avoid damaging the external vertebral venous plexuses (extraspinal veins) responsible for persistent and massive venous hemorrhage. Afterward, dura mater was exposed, and $0.08 \mathrm{ml}$ of bone marrow cell suspension was transplanted using a $0.5 \mathrm{ml}$ syringe with a $31 \mathrm{G}$ needle (Glinkowski and Ciszek 2000; Muldoon et al. 2013). This stage requires meticulous attention as rapidly injected fluid in the subarachnoid space could induce cerebrospinal fluid hypertension, potentially leading to the irreversible complications. The needle was gently removed, and the needle hole was covered in dura mater with the previously prepared paraspinous muscle patch and silked with bone wax if necessary. Subcutaneous tissue and skin were adapted by running 4-0 absorbable sutures.

\section{Preparation of Donor BMC}

According to our well-established technique, bone marrow cells were prepared from the $\mathrm{ACI}(\mathrm{RT} 1 \mathrm{a})$ rat femoral bones (Klimczak et al. 2007). Before transplantation, BMC was labeled with red fluorescent membrane dye PKH-26 (Sigma-Aldrich, UK) in the Diluent $\mathrm{C}$ buffer solution for $5 \mathrm{~min}$. Labeling was stopped by incubation with $1 \%$ bovine serum albumin in phosphate-buffered saline (PBS) for $1 \mathrm{~min}$ and complete $\alpha$-MEM medium. PKH-26 labeled BMC were prepared to a final concentration of $100 \times 10^{6}$ cells (Tario et al. 2007).

\section{Immunosuppressive Protocol}

In all treatment groups, alpha/beta-TCR monoclonal antibodies $(\mathrm{mAb})$ and Cyclosporine A (CsA) (Novartis, East Hanover, NJ) were administered $1 \mathrm{~h}$ before surgery. CsA was injected subcutaneously $(16 \mathrm{mg} / \mathrm{kg} /$ day $)$, and intraperitoneal injection of alpha/beta-TCR mAb (250 mg/day) (clone R73, Pharmingen, San Diego, CA) was administered simultaneously with CsA during the 7-day protocol. The efficacy of immunosuppressive drug administration was monitored by the serum level of CsA and alpha/beta-TCR checking simultaneously with blood sample harvesting (Siemionow et al. 2005a).

\section{Clinical Evaluation of Graft-versus-Host Disease}

The animals' general health and weight were monitored throughout the study. According to the previously published criteria, recipients were clinically evaluated for the presence of the graft-versus-host disease (GVHD) signs, including unkempt appearance, diffuse erythema (particularly mucosa and ear), hair loss, diarrhea, and rash of paws or snout, and failure to thrive (Kanitakis 2008). Diagnostics included daily measurement of body weight during the first month and then at weekly intervals.

\section{Assessment of Transplant Viability and Histological Evaluation}

The skin island's viability was assessed by observing the skin allograft transplants by the same surgeon (AJ). The survival of the VSA skin transplant was evaluated during the postoperative follow-up period by assessing the flap color, edema, erythema, hair loss, and necrosis compared with healthy skin (Fig. 3). Skin "punch" biopsies from the donor VSA and the contralateral skin recipients 21,35 , and 63 days after transplantation were performed unless rejection onset was identified. After clinical symptoms indicating skin rejection emerged, we collected additional skin biopsies from both the VSA and healthy skin from the recipient groin area for better collation. To evaluate the histological grade of acute rejection, the Buttemeyer standard scale was used: Stage 0-the correct appearance of the epidermis with no signs of rejection; Stage 1-focal infiltration of mononuclear cells, vacuolation of the basal layer of the epidermis; Stage 

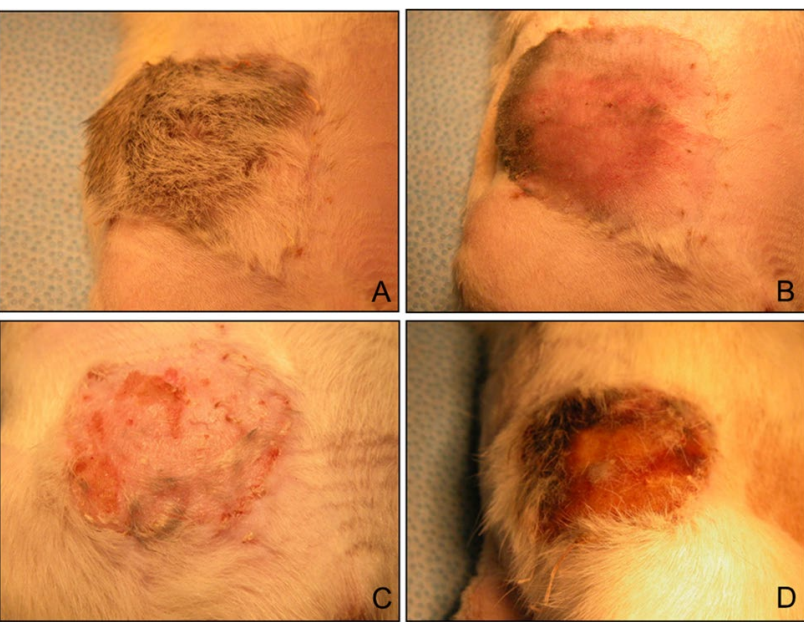

Fig. 3 Clinical assessment of VSA rejection in Group 4 after intrathecal BMT: A no signs of rejection at day $35 ; \mathbf{B}$ inflammation phase at day 58; $\mathbf{C}$ progression of rejection at 63 days, $\mathbf{D}$ necrosis: complete rejection at day 72 post-transplant

2-blistering suprabasal layer and mixed cellular infiltration; Stage 3-marked edema, vasculitis, and necrosis (Büttemeyer et al. 1996). At the end of the observation, we harvested the necrotic transplanted flap of skin from the donor $\mathrm{ACI}$ and an unoperated portion of the Lewis' recipient skin.

Additionally, the liver, spleen, kidney, thymus, and three to four lymph nodes from the front of the neck were collected for further evaluation. For histological examination, graft and recipient tissues were fixed in $10 \%$ neutral buffered formalin (Sigma-Aldrich, USA) and embedded in paraffin before tissue sectioning and H\&E staining. A pathologist evaluated the histology slides under a light microscope for the viability of skin, muscle, and bone, for the presence of hematopoietic cells, and for signs of fibrosis and rejection. Two pathologists blinded to the group assignment performed the assessments.

\section{Evaluation of BMC for the Presence of Donor-Specific Chimerism}

Peripheral blood samples were taken at day 7, 21, 35, and 63 days post-transplantation from the external jugular vein. Additional blood samples were taken at clinical signs of rejection. For assessment of ACI donor chimerism, combinations of conjugated mouse anti-rat RT1 ${ }^{\text {a }}$-FITC (for MHC class I of donor cells, clone C3, BD Pharmingen) with CD4-PE (clone OX-35), CD8a-PE (clone OX-8), and CD45RA-PE (clone OX-33) were used. After incubation, a lysing solution was used, and then samples were fixed with a 1\% paraformaldehyde (PFA) solution. Opposing control panels were tested and included isotype-matched antibodies $\mathrm{IgG}_{1}-\mathrm{FITC} / \mathrm{IgG}_{2}-\mathrm{PE}$ and PBS samples. The analysis was performed on $1 \times 10^{4}$ cells, using FACS SCAN (BD Pharmingen) and FlowJo software (Siemionow et al. 2005b, 2008).

\section{Assessment of Engraftment of PKH-26 + Stained Donor-Origin Cells by Immunofluorescence Analysis}

Cell trafficking potential and engraftment of donor-origin cells into lymphoid and non-lymphoid organs of VSA allograft recipients was assessed based on immunofluorescence signal delivered from PKH-26 labeled cells. Frozen tissue samples of lymph nodes, thymus, and skin punch biopsies of both donor and recipient were harvested randomly during blood sample harvesting on 7, 21, 35, and 63 days posttransplantation. Also, partial splenectomies were performed at 35 and 63 days after transplantation to one representative in each Group. Tissue sections were cut into $4 \mu \mathrm{m}$ sections and dried for $40 \mathrm{~min}$ at room temperature, then fixed in cold $\left(-20^{\circ} \mathrm{C}\right)$ acetone for $10 \mathrm{~min}$ and rinsed three times for $5 \mathrm{~min}$ in PBS. DAPI solution (Vectashield mounting media) was applied to each sample. The specimens were analyzed for the presence of $\mathrm{PKH}-26$ positive cells using a fluorescence microscope.

\section{Statistical Analysis}

Results were reported as mean \pm standard deviation (SD). The VSA survival rates in treatment groups were evaluated by the ANOVA method. The level of chimerism (ACI $\left(\mathrm{RT}^{\mathrm{a}}\right)$, $\mathrm{CD} 4 /\left(\mathrm{RT}^{\mathrm{a}}\right), \mathrm{CD} 8 /\left(\mathrm{RT}^{\mathrm{a}}\right), \mathrm{CD} 45 \mathrm{RA} /\left(\mathrm{RT}^{\mathrm{a}}\right)$, presence of $\mathrm{CD} 4{ }^{+} / \mathrm{CD} 25^{+} \mathrm{T}$ cells, and efficacy of the immunosuppressive treatment was compared by Statistica 9.0 and Student's $t$ test. The significance of changes in the studied chimerism parameters in time was assessed by $t$ test. Differences between groups were considered significant at $p<0.05$ (Domański 1979).

\section{Results}

\section{Assessment of GVHD}

There was no decrease in body weight compared to the preoperative level. All animals were in good general condition. There were no characteristic GVHD symptoms, such as hair loss and skin color, specifically with changes around the ears, diarrhea, or shortness of breath. None of the animals showed any sign of GVHD during follow-up examination. Moreover, there was no confirmation of GVHD in histology assessment. All wounds healed initially, and there was no postoperative wound infection. There were no complications associated with BMC transplantation procedures into immune-privileged regions. 


\section{Clinical Assessment of VSA Transplants}

All animals survived the early postoperative period without any complications, and all wounds healed. There were no postoperative wound infections or complications associated with bone marrow donors' transplantation into recipient immunologically privileged compartments. The patency of vessels supplying the transplanted vascularized flap was confirmed by intraoperative macroscopic examination during blood sampling at 21 days post-transplantation procedure.

The controls without cellular therapy rejected VSA between 26 and 41 days (34.6 \pm 5.5$)$ after the transplantation procedure. Allografts in Group 2 and Group 3 were rejected between $28-57(36.4 \pm 12.5)$ and $29-69(46.3 \pm 16.3)$ days, respectively (Table 1). The most prolonged allograft survival, 50-78 (62.4 \pm 10$)$ days, was achieved in Group 4

Table 1 The onset of VSA rejection

\begin{tabular}{lcccc}
\hline & \multicolumn{4}{c}{ Comparison of rejection between groups } \\
\cline { 2 - 5 } & Group 1 & Group 2 & Group 3 & Group 4 \\
\hline$N$ & 7 & 7 & 7 & 7 \\
$\begin{array}{l}\text { Average onset of } \\
\text { VSA rejection } \\
\text { (days) }\end{array}$ & 28.43 & 28.00 & 38.57 & 49.14 \\
$\begin{array}{l}\text { Average duration } \\
\text { of the rejection } \\
\text { process (days) }\end{array}$ & 6 & 8 & 8 & 12 \\
\begin{tabular}{l} 
SD \\
\hline
\end{tabular} & 7.59 & 12.15 & 15.31 & 9.30 \\
\hline
\end{tabular}

Group 1: Control, without BMC supportive therapy; Group 2: Intracapsular BMC $\left(100 \times 10^{6}\right.$ cells) transplantation; Group 3: Intragonadal BMC $\left(100 \times 10^{6}\right.$ cells) transplantation; Group 4: Intrathecal BMC $\left(100 \times 10^{6}\right.$ cells $)$ transplantation. Noteworthy is the different length of the rejection process in individual groups. Longest average rejection was observed in Group 4 (12 days) and the shortest time of rejection was observed in Control Group 1 (6 days) after intrathecal BMT (Fig. 4). Average allogeneic skin flap survival was statistically significant in Groups 4 and $3(p=0.001$ and $p=0.002)$ compared with control Group 1. In contrast, median survival in Group 2 was not statistically different from Group 1 . The longest-individual VSA survival was observed in Groups 4, 3, 2, and 1, respectively, consistent with average survival time in different groups. VSA skin flaps' survival time in Group 4 was significantly longer than Group 1 and 2 ( $p=0.001$ and 0.002 , respectively). The survival curves for all experimental groups are plotted in (Fig. 4).

\section{Histological Examination of VSA}

In all groups, skin biopsies were taken from the donor VSA the first week after transplantation, and recipient skin biopsies revealed no histological changes and rated grade 0 on a rejection scale (Fig. 5).

In allograft rejection controls (no BMT), flaps showed clinical signs of rejection after 14 days post-transplantation. It was 7 days after immunotherapy cessation with single focal infiltrates of mononuclear cells with moderate infiltration of lymphocytic cells in the dermis upper layer-grade 1 Buttemeyer's scale. However, in other groups simultaneously, skin biopsies showed normal epidermis and dermis (grade 0 on the rejection scale). All flaps showed clinical signs of completed rejection between 26 and 41 days posttransplant in allograft rejection controls. All skin graft biopsies were randomly taken from the animal of each Group, respectively. Group 2 (intracapsular Group) revealed histopathological third-degree rejection symptoms with clearly marked necrosis of the epidermis with mixed cell infiltration involving the entire thickness of the skin and subcutaneous tissue with small diameter perivascular inflammatory process between 28 and 57 days post-transplantation procedure.

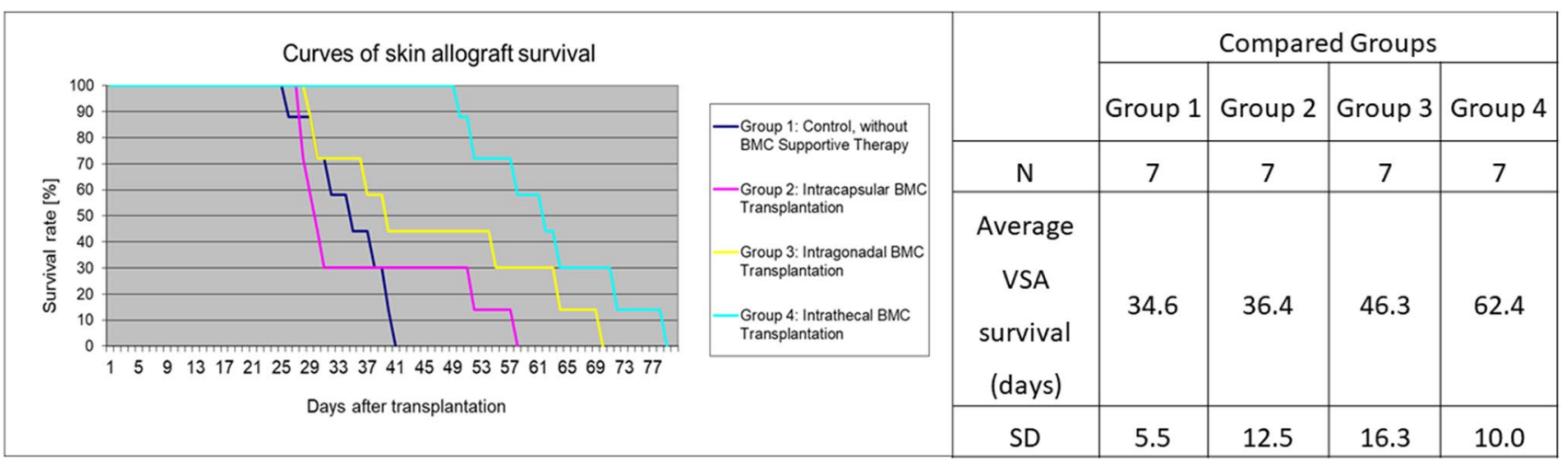

Fig. 4 Skin allograft survival time. Group 1: Control, without BMC supportive therapy; Group 2: Intracapsular BMC $\left(100 \times 10^{6}\right.$ cells $)$ transplantation; Group 3: Intragonadal BMC $\left(100 \times 10^{6}\right.$ cells $)$ transplantation; Group 4: Intrathecal BMC $\left(100 \times 10^{6}\right.$ cells $)$ transplantation. The controls without cellular therapy rejected VSA between 26 and 41 days after transplantation. Allografts in Group 2 and Group 3 were rejected between $28-57$ and 29-69 days, respectively. The longest allograft survival of 50-78 days was achieved in Group 4 after intrathecal BMT transplant 

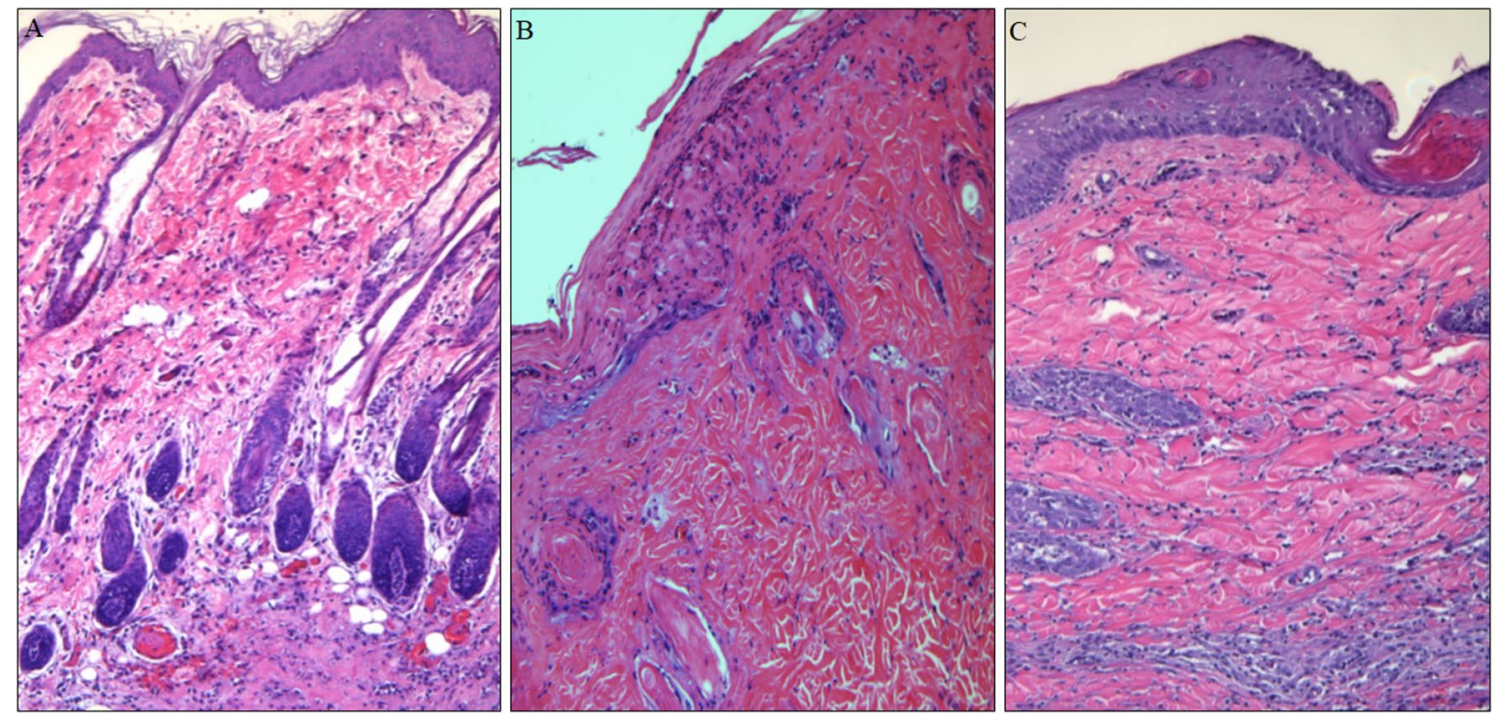

Fig. 5 Hematoxylin and eosin staining of the skin samples during the rejection process, presenting the dynamics of the allogeneic skin flap rejection process in a Control Group I. The samples represent a rejec-

Skin biopsies taken from VSA in Groups 3 and 4 during the first clinical symptoms of rejection revealed epidermis focal infiltrates composed of mononuclear cells with little infiltration in the initial dermis stage rejection (average onset 38.57 vs. 49.14). Monitoring the rejection process assessed on the skin allograft biopsies taken from each experimental Group allowed us to conclude that the dynamics of the VSA rejection process were much slower in the intrathecal Group when compared with the other Groups. The most protracted average lasting VSA rejection process was observed in Group 4 (12 days), then in Group 3 (8 days) and Group 2 ( 8 days) (Table 1). The rejection process's duration was the most aggressive in Group 1, lasting six or fewer days.

\section{Engraftment of the Donor Origin Cells into the Lymphoid and Non-lymphoid Tissues of the Recipient}

Engraftment of donor-origin cells, identified by PKH-26 expression, at evaluation time points $(7,21,35$, and 63$)$ posttransplant was confirmed in the spleen and lymph nodes, but not in the thymus of VSA allograft recipients. In the spleen, numerous donor-derived cells were localized. However, no significant differences in donor cell redistribution intensity were observed in tissue among evaluated groups. Both donor and recipient skin biopsies revealed PKH-26+ stained cells. Moreover, specific accumulation of donor cells, an average of two to three per one hair follicle in the dermis, was observed. The highest cell engraftment in airfoil vascularized and contralateral native skin recipients were evaluated tion of VSA flaps after 14 days-Grade I (A), 21 days-Grade II (B), and Grade III -32 days after transplantation. Magnification $(\times 400)$

in Group 4 after intrathecal BMC transplantation at 7 and 21 days post-transplantation (Fig. 6).

\section{Flow Cytometry for Determination of Donor-Specific Chimerism}

The multilineage donor-specific chimerism $\left(\mathrm{ACI}, \mathrm{RT} 1^{\mathrm{a}}\right)$ was assessed as the sum of donor $\mathrm{T}$ lymphocytes (RT1 ${ }^{\mathrm{a}} / \mathrm{CD} 4$ and $\mathrm{RT} 1 \%$ CD8) and B (RT1\%CD45RA) cells. The chimerism values are presented in the figure (Fig. 7). The multilineage donor-specific chimerism (ACI, RT $1^{\mathrm{a}}$ ) in all active groups followed a hyperbolic descending curve course as a function of time. The highest level of donor specific chimerism was observed seven days following BMT in each treatment group compared to the other time points, respectively. During the follow-up period, the peripheral blood's highest chimerism level was found in the intracapsular Group (Group 2). The assessment of total donor chimerism RT1 $1^{\mathrm{a}}$, presented in Fig. 7, indicates that 2 months after the transplantation procedure, the highest level of chimerism was detected in the intracapsular Group 2 (7.21\%).

In contrast, the lowest level of chimerism was found in the intrathecal Group 4 (1.92\%). In all groups, the chimerism level gradually decreased over the entire follow-up period; however, slight increases was noticed in the intracapsular and intrathecal Groups on day 63 and day 78, respectively. The lowest chimerism levels were observed between days 35 and 63 in Group 4, where bone marrow cells were transplanted into the cerebrospinal fluid via intrathecal injection. However, in Group 4, after 78 days, the total value of the donor chimerism $\left(\mathrm{RT}^{\mathrm{a}}{ }^{\mathrm{a}}\right.$ ) increased to $6.85 \%$. Assessment 
Fig. 6 Immunohistological assessment of the engraftment of PKH stained BMC in different time points after intrathecal bone marrow injection with simultaneous VSA transplantation

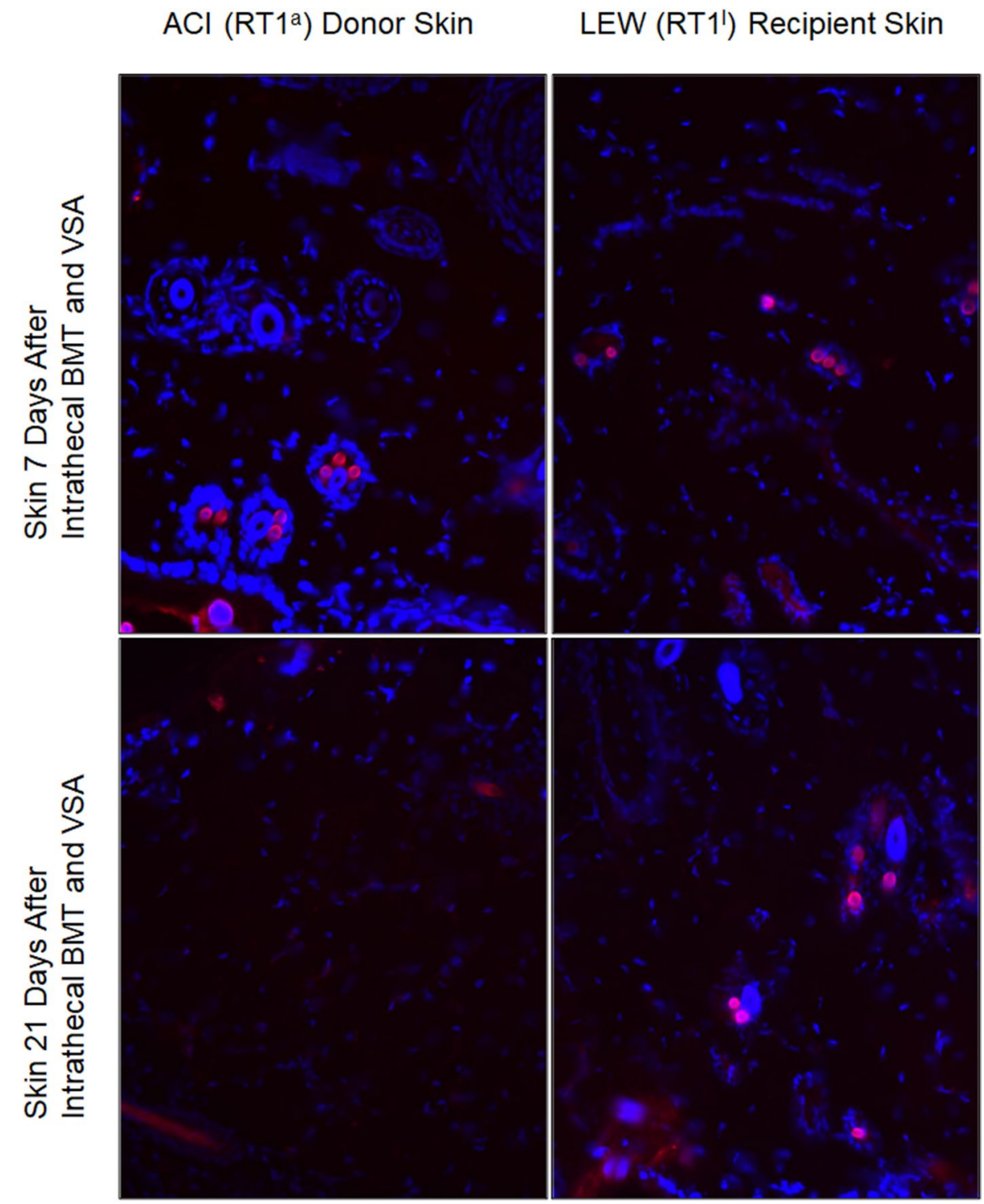

of chimerism kinetics showed a sharp decline of $40 \%$ in each cell subpopulation between 7 and 21 days after transplantation.

The mean value of B cells (RT1a/CD45RA) at 7 days after transplantation in Group 3 exceeded $2 \%$ and over time $\mathrm{B}$ cell values ranged between 0 and $1.05 \%$, except for day 35 in Group 4, where B cell chimerism value exceeded $1.26 \%$ and was significantly higher than on day $21-0.42 \%$. Besides day 21, the level of B cells (RT1a/CD45) of donor-origin was stable only in Group 4. Moreover, there were differences at day 21 between groups 1 and 3 and 1 and $4 p<0.047$ and $p<0.007$, respectively. On day 35 , statistically significant differences were noted between Groups 1 and 3 and 2 and $4, p<0.008 p<002$, respectively. In all groups, the mean values were lower than in the control group (Fig. 8).

The highest $\mathrm{T}$ cell $\mathrm{CD}^{+} / \mathrm{CD}^{2} 5^{+}(7.91 \%)$ level was found on day 7 in the intragonadal injection group.
However, the highest levels of $\mathrm{CD} 4^{+} / \mathrm{CD} 25^{+} \mathrm{T}$ lymphocytes at days 21 and 35 were observed at the intrathecal Group, $6.23 \%$ and $6.93 \%$, respectively (Fig. 9.). The significant differences in $\mathrm{T}$ lymphocytes $\mathrm{CD} 4^{+} / \mathrm{CD} 25^{+}$ values were noticed on 21 days between the control and intrathecal Group $2.12 \%$ vs. $6.24 \%$ ( $p<0.0002)$. In Groups 1,2 , and 3 , the number of $\mathrm{CD} 4^{+} / \mathrm{CD} 25^{+}$cells revealed a decrease over time. In group 4 , there was an increasing trend in $\mathrm{CD} 4{ }^{+} / \mathrm{CD} 25^{+}$cells up to 35 days post-transplant, followed by a decrease starting at day 63 post-transplant (Fig. 9). Comparison of the $\mathrm{CD} 4^{+} / \mathrm{CD} 25^{+} \mathrm{T}$ cells values as the function of time revealed significant decreased of $\mathrm{CD} 4^{+} / \mathrm{CD} 25^{+} \mathrm{T}$ cell in Group 1 and $3(p<0.02$ and $p<0.03$, respectively), with no statistically significant differences observed over time in Group 2 and $4(p=0.25$, $p=0.16)$. 


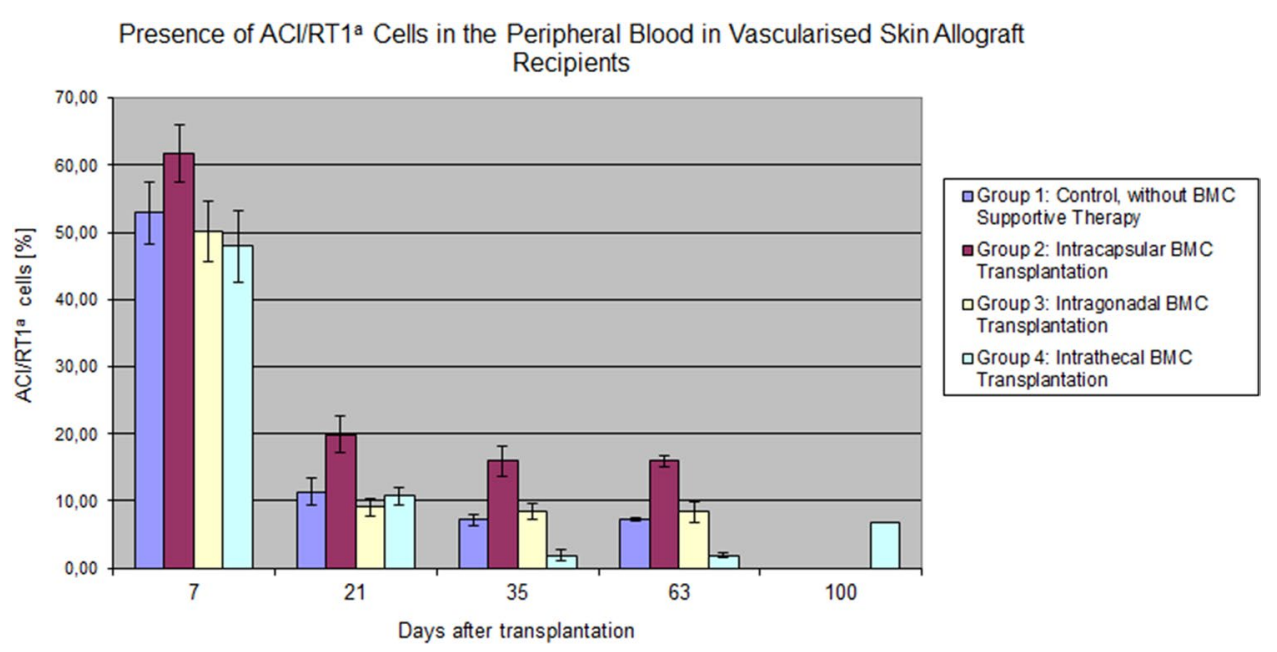

Fig. 7 Comparison of the ACI/RT1a donor-specific chimerism in the peripheral blood of the recipient. Total chimerism was calculated as the sum of the $\mathrm{T}$ cells (RT1a/CD4, RT1a/CD8), B cells (RT1a/ CD45RA), and monocyte/granulocyte (RT1a/CD11b/c) lymphocytes and is presented as mean values with the standard deviations. The peak in chimerism values was observed on day 7 after donor bone marrow transplantation. The highest values were reveled in the Group after administration of BMC cells under the renal capsule at each observation time. In all groups, chimerism decreased over time until day 63 post-transplant. The lowest values were observed between days 35 and 63 post-transplant in the Group receiving intrathecal bone marrow administration to the cerebrospinal fluid. In the intrathecal Group, there was an increase in the total value of the RT1a chimerism up to $6.85 \%$ on day 78 post-transplant
Fig. 8 The presence of RT1a/ CD45RA B lymphocytes in the peripheral blood of the VSA recipients. In Group 3, the mean values for the B cells (RT1a/ CD45RA) at 7 days after transplantation exceeded $2 \%$. Despite the decrease in B lymphocytes levels in Group 4 at day 21 posttransplant, we have observed chimerism stabilization at the level around 1\%

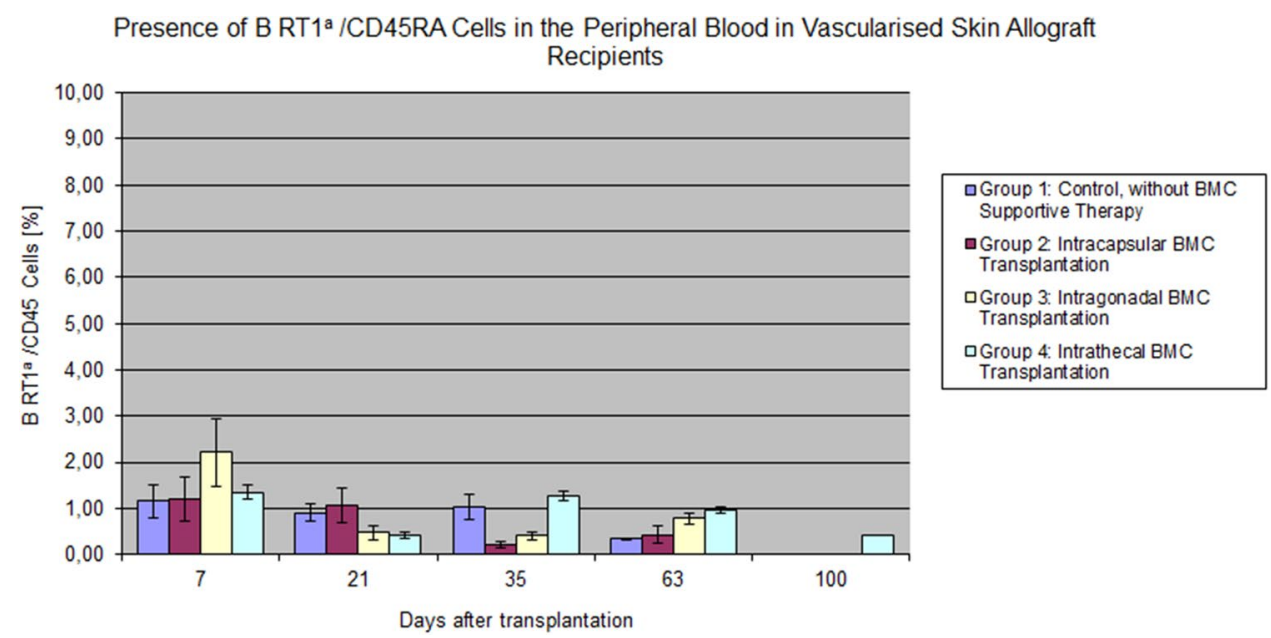

\section{Discussion}

The main goal of transplant surgery is to achieve organ acceptance without lifelong immunosuppressive therapy to prevent transplant rejection (Siemionow 2017). The immunosuppression side effects are the most limiting factor for routine clinical application of VCA and present the critical argument from an ethical perspective against use of allograft transplantation in the procedures that improve quality of life rather than are saving the life (Morelon et al. 2012). In the last 2 decades a significant progress was made in the application of the non-myeloablative protocols and by introduction of a new immunosuppressive drugs to induce tolerance to in VSA (Hivelin et al. 2016). Numerous studies confirmed the beneficial role of donor-specific chimerism in allograft survival, but other reports suggest no connection between chimerism and tolerance. Therefore, investigations on non-animal models are conducted to acknowledge this correlation (Hartung and Corsini 2013; Schnider et al. 2013). It was recognized that the skin manifests the highest immunogenicity of all CTA components, confirmed in the classification of skin-containing composite tissue allograft (Cendales et al. 2006; Leonard et al. 2013b). This survey is complicated because the CTA's transplantation (Schnider et al. 2013). This essential fact highlights the necessity of pursuing new alternative tolerance induction protocols (Leonard et al. 2013a). 
Fig. 9 The presence of the Treg cells in the peripheral blood of the recipient. The level of Treg cells RT $1{ }^{\text {a }} \mathrm{CD} 4 / \mathrm{CD} 25$ in the peripheral blood was higher after the intrathecal injection compared to the other groups at each time point after transplantation $(p<0.05)$

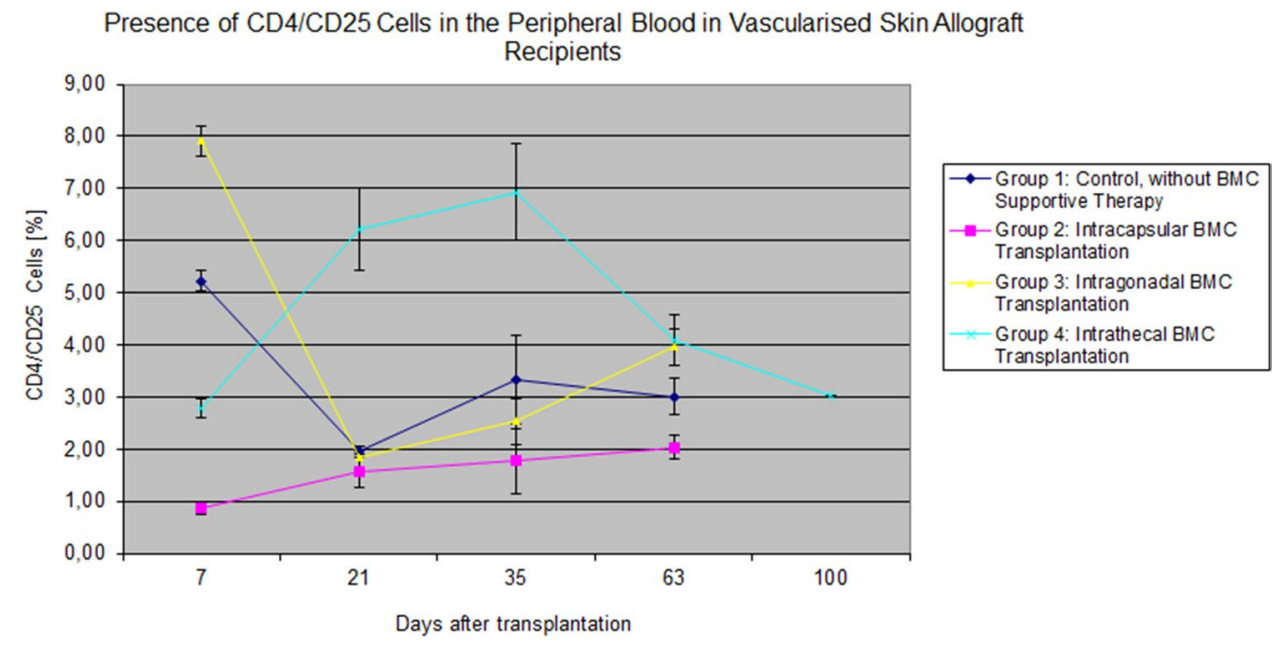

The one promising method for reducing or eliminating lifelong immunosuppression is chimerism induction by simultaneous transplantation of donor bone marrow with VCA transplantation (Xu et al. 2013). Numerous papers on animal models and clinical trials have confirmed the correlation between chimerism and VCA survival, but some investigators are skeptical (Kashiwagi et al. 1969; Murase et al. 1991). There are many different tolerance induction protocols, including the vascularized whole limb transplantation combined with selected and modified cells line (Ibrahim et al. 2013; Siemionow and Klimczak 2013). It was confirmed that grafting of the vascularized bone containing hematopoietic cells most effectively induces durable chimerism, which correlates with the significant extension of VCA survival (Barth et al. 2011; Bozkurt et al. 2013; Leonard et al. 2013b; Nasir et al. 2010). No scientific reports evaluate the influence of bone marrow transplantation into immunologically privileged regions to induce chimerism and tolerance in the VCA. As pioneers in this research area, we developed an innovative, technical approach for donor BMC transplantation model into the immunoprivileged regions. We also assessed the efficacy of different bone marrow cell transplantation methods on the extension of survival of the allogeneic vascularized skin flaps.

Previous experimental studies confirmed the role of skin components playing the role in the induction of chimerism in the allograft recipients. T lymphocytes, the skin's natural residents, accompany by dendritic cells and Langerhans' cells and play the leading role in chimerism induction, which is proportional to the size of the skin component of the VCA (Leonard et al. 2013a). The size of $16 \mathrm{~cm}^{2}$ of the skin component of the VCA corresponded to more than half of the skin component included in the entire rat total abdominal wall model of $27.92 \mathrm{~cm}^{2}$ (Nasir et al. 2008). The larger skin component involved in VCA transplants induced higher chimerism levels, but the efficacy of induction of the longlasting tolerance via chimerism is weaker when compared with chimerism induction via vascularized bone marrow transplantation (Arslan et al. 2007; Siemionow and Nasir 2007; Siemionow et al. 2005c). In our study, mixed chimerism in the peripheral blood was composed of $\mathrm{T}$ cells (including $\mathrm{CD}^{+}$and $\mathrm{CD} 8^{+}$) and $\mathrm{B}$ lymphocytes. The highest level of chimerism was observed in all groups on day 7 after transplantation and then decreased over time.

Furthermore, higher chimerism levels in the peripheral blood in the control group negatively correlated with VSA survival, where VSA rejection was triggered two times faster than in Group 4, where the BMC was transplanted into the cerebrospinal fluid via intrathecal administration.

Even more interesting seems to be a higher mixed donor chimerism level in the control group, notwithstanding the donor bone marrow cell transplantation. These results are consistent with earlier results from Siemionow et al. (Nasir et al. 2008). These studies confirmed that the low level of whole chimerism in the peripheral blood induced by the skin allograft could not guarantee prolonged VSA survival. According to the literature and presented results, chimerism less than $10 \%$ does not ensure long-term VSA survival (Kanamoto and Maki 2004), in contrast to the survival time of the transplanted organ (Kiyomoto et al. 2006). Our study indicated the importance of different chimeric cell populations playing the role in allograft survival when compared with total chimerism levels below $10 \%$, which is less meaningful. The $\mathrm{T}$ cells decline was accompanied by the maintenance of stable values of B lymphocytes. This suggests $T$ cells' role in the first phase of tolerance induction; however, $\mathrm{B}$ cells are responsible for maintaining the second phase of tolerance (Ashour and Seif 2007; Cowan et al. 2012; Parsons et al. 2009). We observed comparable levels of B cells in all groups, and its decrease below $1 \%$ was associated with the beginning of the VSA rejection process. This affinity 
was seen in all groups-the value of B cell fluctuations correlated with a downgrade in T regulatory cells' level. Many scientific reports confirmed the effect of regulatory $\mathrm{T}$ cells (Treg) on the cellular response and the humoral immune response (Eddahri et al. 2006; Fields et al. 2005; Singh et al. 2012). The prolonged deterioration of the B cell's population in the intrathecal Group reflected prolonged VSA survival (Liu et al. 2009). Previous observations of Prof. M. Siemionow and colleagues' confirm present assessments (Siemionow et al. 2008; Yazici et al. 2007). The explanation of the lower but stable level of donor peripheral blood B lymphocytes than the values obtained in previous Prof. Siemionow's study (Siemionow et al. 2005c) was the lack of an adequate pool of progenitor cells in ours study. The vascularized bone marrow is the largest reservoir of these cells. Therefore, the donor B lymphocytes' level increases significantly after vascularized bone marrow transplantation promoting VSA survival (Klimczak et al. 2006; Lin et al. 2021). This paradox appears due to the delayed redistribution of transplanted cells from immunoprivileged regions, forming a barrier between the external environment and myeloid cells. Moreover, the cells derived from the donor bone marrow migrate and settle in the recipient's lymphoid tissues, with no peripheral blood presence, reflecting the fundamental values of donor chimerism.

Naturally occurring $\mathrm{CD} 4^{+} / \mathrm{CD} 25^{+} \mathrm{T}$ cells constitute up to $10 \%$ of the $\mathrm{CD}^{+}{ }^{+} \mathrm{T}$ cells in rodents' peripheral blood. The majority of these cells express transcriptional factor FoxP3 associated with Treg-cell function. It is well known that most of the naturally occurring $\mathrm{CD} 4^{+} / \mathrm{CD} 25^{+} \mathrm{T}$ cells are produced by the thymus as an antigen-primed and functionally mature T cells subpopulation playing the role in the immunosuppression. Also, some of the $\mathrm{T}$ cells differentiate from the naive conventional $\mathrm{T}$ cells in the periphery and do not require intrathymic preactivation to acquire Treg phenotype and function (Sakaguchi et al. 2008; Yang and Eun 2017). T cells with phenotype CD4/CD25 are essential, particularly in immunoregulation of both the innate and adaptive immune responses, although some reports undermine the validity of these observations (Brazio et al. 2013). In our study, we did not specify $\mathrm{CD} 4^{+} / \mathrm{CD} 25^{+}$cells phenotype with FoxP3. The highest level of $\mathrm{CD} 4^{+} / \mathrm{CD} 25^{+} \mathrm{T}$ lymphocytes was observed in the intrathecal Group. The level of $\mathrm{CD} 4{ }^{+} \mathrm{CD} 25^{+}$tripled at 35 days after transplantation compared to the levels observed at day 7 . The high values of $\mathrm{CD} 4^{+} / \mathrm{CD} 25^{+}$cells correlated with a median skin allografts survival and reached the longest survival rate in Group 4 where BMC were injected into the recipient's cerebrospinal fluid via intrathecal administration. The values of $\mathrm{CD} 4^{+} / \mathrm{CD} 25^{+}$cells observed in the other groups were significantly lower, represented by shortened vascularized flap survival. Besides, the kinetic changes of $\mathrm{CD} 4^{+} / \mathrm{CD} 25^{+}$lymphocytes during the follow-up period were similar in all groups except Group 4. In the intrathecal
Group, we first observed an increasing trend of up to 35 days and decreased thereafter. Cerebrospinal fluid offers the most favorable conditions, guarantees survival and migration of progenitor cells compared to other immunologically privileged regions (Pilat et al. 2010; Zhu et al. 2002). Recent in vitro studies documented that $\mathrm{T}$ lymphocytes can enter the central nervous system directly by crossing the endothelial blood-brain-barrier or enter into the cerebrospinal fluid via the choroid plexus (Nishihara et al. 2020; Strazielle et al. 2016). Thus, intrathecal delivery of BMC can results in "inverse" trafficking of transplanted cells into the systemic circulation, thus enhancing peripheral blood chimerism. This notion can be supported by studies revealing the presence of functional meningeal lymphatic system located in the dura mater and enables cerebrospinal fluid, and the immune cells to drain back to the deep cervical lymph nodes (Louveau et al. 2015). Therefore, allogeneic antigens present on the transplanted BMCs can trigger naïve T lymphocytes residing in the lymph nodes for differentiation into the functional $\mathrm{CD} 4{ }^{+} \mathrm{CD} 25^{+}$Tregs that are engaged in the suppressing of the immune responses towards transplanted allografts (Paiva et al. 2013; Sakaguchi et al. 2008).

Treg cells are critical for maintaining tissue (immune) homeostasis mainly by exerting suppressive function on the naïve or effector $\mathrm{T}$ cells. In transplantation tolerance, Tregs can function to regulate alloimmune response through several mechanisms, including secretion of the immunosuppressive cytokines (TGF- $\beta$ and IL-10), modulation of the antigen-presenting cell (APC) function (e.g., downregulation of expression of dendritic cells co-stimulatory molecules, or by direct suppression of $\mathrm{CD} 8^{+}$and $\mathrm{CD} 4^{+}$effector cells by cell-to-cell contact (Rahhal et al. 2009; Sakaguchi et al. 2008). Experimental studies on spinal Treg cells delivery and intrathecal Treg-dependent IL-35 delivery proved that these cells reduced pain associated with encephalomyelitis in the experimental autoimmune encephalomyelitis mice model. This was associated with the upregulation of IL-10 expression (Duffy et al. 2019). Functional activity of Treg assessed in osteomyocutaneous VCA mouse model showed that depletion of Treg at day 30 after allograft transplantation is leading to allograft rejection. Moreover, Treg from tolerant mice showed more significant suppressive potential and the ability to rescue allografts from rejection, thus confirming that circulating Treg's are crucial for tolerance induction in VCA in the early post-transplant period (Anggelia et al. 2021). This study also confirmed that an elevated level of IL-10 was associated with the protolerogenic function of Treg.

Moreover, two more mechanisms' are responsible for increased cell survival in the immunoprivileged compartments: MHC APO-1/FasL expression and low level of APCs due to the low lymph drainage. Moreover, $\mathrm{CD} 4^{+} / \mathrm{CD} 25^{+}$ cells decreased at the observation time in both intragonadal 
and intrathecal groups, confirming these compartemnets as the preferable injection sites leading to the prolonged VSA survival ( $p=0.002$ and $p=0.001)$ when compared with the control group. Moreover, in the intrathecal Group, the increased number of the Treg lymphocytes when compared with a control group has established the intrathecal compartment with cerebrospinal fluid as the preferred site for $\mathrm{BMC}$ transplantation which was confirmed by triggering of the CD4/CD25 cells in the peripheral blood. We observed the statistically significant difference in the decreased CD4/ CD25 cells' value in the control and intracapsular Groups $(p<0.02, p<0.03)$. Furthermore, immunoprivileged compartments guaranteed the transplanted BMC protection against annihilation. Furthermore, the role of B cell chimerism should be mentioned, since considering the functional similarities of regulatory $\mathrm{B}$ cells and regulatory $\mathrm{T}$ cells allows to assume that increased B-cell chimerism in the intrathecal BMC group enhanced the immunosuppressive effect of Tregs and extended VCA survival (Lee et al. 2014).

The engraftment process was supported by selective blockage of alloreactive T cells by anti-alfa/beta-TCR antibodies preserving tolerogenic potential of gamma/delta $\mathrm{T}$ lymphocytes (Shevach 2006). The first clinical trials with intrathecal BMC transplantation reported promising outcomes (Gahrton et al. 1991), however, more clinical trials and investigations are needed to support routine application of this protocol.

The transplantation procedure was not burdened by the GVHD, regardless of the privileged site of BMC transplantation. This observation is consistent with previous reports, which assessed the combined application of the immunosuppressive protocol with BMC transplantation in the CTA model (Siemionow et al. 2012; Xu et al. 2013). The lack of GVHD can be explained either by the selective immunosuppressive potential of the alpha/beta TCR protocol or by the use of CsA. The CsA treatment inhibits predominantly production of IL-2, resulting in a lack of $\mathrm{T}$ cell proliferation and thereby facilitates donor BMC engraftment. A 7-day immunosuppression protocol combined with BMCs transplantation creates an immune-privileged window for the Treg cells migrations to the immunologically reactive regions (Janssens et al. 2003; Walch and Lakkis 2014). Engraftment of donor cells into both the lymphoid and non-lymphoid organs of the recipient presented the Starzl innovatory chimerism theory (Starzl 1971) indicating that only constant contact of the donor cells with the recipient lymphoid organs warrants transplantation tolerance induced by chimerism. The immune protection mechanism is based on the isolation of foreign antigens by the mechanical and immunological barrier created by the recipient's immunoprivileged sites. This development is critical because the robust migration of the APC from the VCA donor in the initial phase of transplantation triggers a significant immune response in the recipient
(Hoffman et al. 1989). The immunoprivileged regions possess several innate mechanisms such as an anatomical barrier, increased Treg cell activity, increased activation of IL-10 and TGF- $\alpha$, and membrane FasL factor (D'Alessio et al. 2001). These mechanisms steered activated Treg cells to apoptotic death. Due to these reasons, allograft acceptance without the need for an immunosuppressive "umbrella" may have occurred (Krajewska et al. 2006).

The limitation of this study is the lack of functional assessment on the correlation of the levels of $\mathrm{CD} 4^{+} / \mathrm{CD} 25^{+}$ cells with increased graft survival in the intrathecal Group. However, this study was focused on the assessment of the best-immunoprivileged compartment for BMC delivery which would correlate with VCA survival. Thus, the current study is considered as a pilot study searching for the best-immunoprivileged tissue/organ which will be chosen for the further studies assessing the impact of $\mathrm{CD} 4^{+} / \mathrm{CD} 25^{+}$ cells on functional immune activity and donor-specific tolerance in the allograft recipients. However, despite these limitations, the present study adds a novel observation of application and delivery of the BMC supportive therapy into immunoprivileged compartments as a potential tool for tolerance-inducing strategies, an extension of VCA survival.

\section{Conclusions}

Our protocol is short, selective, and minimally toxic and creates optimal conditions for implantation of both cells of foreign origin and allows for the coexistence of these cells in one organism (Nikolic et al. 2010; Siemionow and Klimczak 2009). The assurance of the dynamic correlation between the donor and recipient cells illustrates the chimerism-inducing phenomenon, limiting the need for lifelong immunosuppressive therapy (Leonard et al. 2012). Seven days of immunomodulatory therapy with the donor bone marrow cells sensitization in the immunologically privileged regions created the favorable conditions for allogeneic BMT and subsequent intra-bone marrow engraftment (Siemionow and Klimczak 2010). The presence of donor chimerism in the recipient's peripheral blood and lymphoid organs promotes survival of the vascularized skin allografts. Supportive intrathecal (to the cerebrospinal fluid) transplantation of the BMC is more effective in extending the survival of the vascularized skin allografts compared to the BMC injection into the immuno-privileged regions under the kidney capsule or into the testis. Intrathecal transplantation is associated with the higher levels of the subpopulation of $\mathrm{CD} 4^{+} / \mathrm{CD} 25^{+}$ $\mathrm{T}$ cells in the peripheral blood which is corresponding with a stable levels of the donor B cells RT1\%/CD45RA population. These results are promising and may be applied as a novel immunomodulatory therapy for tolerance induction in CTA (Oh et al. 2020). 
Acknowledgements The authors thank James R. Gatherwright, MD, Cleveland Clinic flow cytometry and imaging cores for technical support in the study.

Author contributions Conception and design: AJ and MS. Analysis and interpretation: AJ, AK, and JK. Data collection: AJ and GB. Writing the article: AJ. Critical revision of the article: MS and AK. Final approval of the article: MS. Statistical analysis: AJ. Obtained funding: MS. Overall responsibility: MS.

Funding This work was supported by funding from the Department of Defense Armed Forces Institute of Regenerative Medicine (AFIRM, W81XWH-08-2-0034).

Availability of data and material All data generated in this study are included in the manuscript. Moreover, they are available for presentation upon request.

Code availability Not applicable.

\section{Declarations}

Conflict of interest The authors have no financial conflict of interest.

Ethics approval This study was approved by Cleveland Clinic's Institutional Animal Care and Use Committee (IACUC \#2012-0841, Cleveland, Ohio), which is accredited by the American Association for the Accreditation of Laboratory Animal Care (AAALAC).

Consent to participate Not applicable.

Consent for publication Not applicable.

Open Access This article is licensed under a Creative Commons Attribution 4.0 International License, which permits use, sharing, adaptation, distribution and reproduction in any medium or format, as long as you give appropriate credit to the original author(s) and the source, provide a link to the Creative Commons licence, and indicate if changes were made. The images or other third party material in this article are included in the article's Creative Commons licence, unless indicated otherwise in a credit line to the material. If material is not included in the article's Creative Commons licence and your intended use is not permitted by statutory regulation or exceeds the permitted use, you will need to obtain permission directly from the copyright holder. To view a copy of this licence, visit http://creativecommons.org/licenses/by/4.0/.

\section{References}

Anggelia MR, Cheng HY, Chuang WY et al (2021) Unraveling the crucial roles of FoxP3+ regulatory T cells in vascularized composite allograft tolerance induction and maintenance. Transplantation 105:1238-1249. https://doi.org/10.1097/TP.0000000000003509

Arslan E, Klimczak A, Siemionow M (2007) Chimerism induction in vascularized bone marrow transplants augmented with bone marrow cells. Microsurgery 27:190-199. https://doi.org/10.1002/ micr.20330

Asari S, Itakura S, Rawson J et al (2011) Mesenchymal stem cells facilitate mixed hematopoietic chimerism induction and prevent onset of diabetes in nonobese diabetic mice. Pancreas 40:846-854. https://doi.org/10.1097/MPA.0b013e318215cdce
Ashour HM, Seif TM (2007) The role of B cells in the induction of peripheral T cell tolerance. J Leukoc Biol 82:1033-1039. https:// doi.org/10.1189/jlb.0507310

Barth RN, Rodriguez ED, Mundinger GS et al (2011) Vascularized bone marrow-based immunosuppression inhibits rejection of vascularized composite allografts in nonhuman primates. Am J Transplant 11:1407-1416. https://doi.org/10.1111/j.1600-6143. 2011.03551.x

Bozkurt M, Klimczak A, Nasir S et al (2013) Composite osseomusculocutaneous sternum, ribs, thymus, pectoralis muscles, and skin allotransplantation model of bone marrow transplantation. Microsurgery 33:43-50. https://doi.org/10.1002/micr.22023

Brazio PS, Munivenkatappa RB, Bojovic B et al (2013) Regulatory $\mathrm{T}$ cells are not predictive of outcomes in a nonhuman primate model of vascularized composite allotransplantation. Transplantation 96:267-273. https://doi.org/10.1097/TP.0b013e3182 $98 \mathrm{dcff}$

Büttemeyer R, Jones NF, Min Z et al (1996) Rejection of the component tissues of limb allografts in rats immunosuppressed with FK-506 and cyclosporine. Plast Reconstr Surg 97:139-148 (discussion 149-151)

Cendales LC, Kirk AD, Moresi JM et al (2006) Composite tissue allotransplantation: classification of clinical acute skin rejection. Transplantation 81:418-422. https://doi.org/10.1097/01.tp.00001 85304.49987.d8

Cendales LC, Kanitakis J, Schneeberger S et al (2008) The Banff 2007 working classification of skin-containing composite tissue allograft pathology. Am J Transplant 8:1396-1400. https://doi.org/10. 1111/j.1600-6143.2008.02243.x

Cowan ML, Sciammas R, Chong AS (2012) Experimental models of B cell tolerance in transplantation. Semin Immunol 24:77-85. https://doi.org/10.1016/j.smim.2011.08.018

D'Alessio A, Riccioli A, Lauretti P et al (2001) Testicular FasL is expressed by sperm cells. Proc Natl Acad Sci USA 98:3316-3321. https://doi.org/10.1073/pnas.051566098

Domański C (1979) Statystyczne testy nieparametryczne. Państwowe Wydawnictwo Ekonomiczne

Duffy SS, Keating BA, Perera CJ et al (2019) Regulatory T cells and their derived cytokine, interleukin-35, reduce pain in experimental autoimmune encephalomyelitis. J Neurosci 39:2326-2346. https:// doi.org/10.1523/jneurosci.1815-18.2019

Eddahri F, Oldenhove G, Denanglaire S et al (2006) CD4+ CD25+ regulatory $\mathrm{T}$ cells control the magnitude of $\mathrm{T}$-dependent humoral immune responses to exogenous antigens. Eur J Immunol 36:855863. https://doi.org/10.1002/eji.200535500

Fields ML, Hondowicz BD, Metzgar MH et al (2005) CD4+ CD25+ regulatory $\mathrm{T}$ cells inhibit the maturation but not the initiation of an autoantibody response. J Immunol 175:4255-4264

Fijak M, Meinhardt A (2006) The testis in immune privilege. Immunol Rev 213:66-81. https://doi.org/10.1111/j.1600-065X.2006. 00438.x

Fijak M, Bhushan S, Meinhardt A (2011) Immunoprivileged sites: the testis. Methods Mol Biol 677:459-470. https://doi.org/10.1007/ 978-1-60761-869-0_29

Gahrton G, Tura S, Ljungman P et al (1991) Allogeneic bone marrow transplantation in multiple myeloma. European Group for Bone Marrow Transplantation. N Engl J Med 325:1267-1273. https:// doi.org/10.1056/NEJM199110313251802

Glinkowski W, Ciszek B (2000) The anatomy of surgical approaches to the cervical spine. Ortop Traumatol Rehabil 2:85-90

Gordon CR, Siemionow M, Zins J (2009) Composite tissue allotransplantation: a proposed classification system based on relative complexity. Transplant Proc 41:481-484. https://doi.org/10.1016/j. transproceed.2009.01.025 
Hartung T, Corsini E (2013) Immunotoxicology: challenges in the 21st century and in vitro opportunities. Altex 30:411-426. https://doi. org/10.14573/altex.2013.4.411

Hivelin M, Klimczak A, Cwykiel J et al (2016) Immunomodulatory effects of different cellular therapies of bone marrow origin on chimerism induction and maintenance across MHC barriers in a face allotransplantation model. Arch Immunol Ther Exp 64:299 310. https://doi.org/10.1007/s00005-015-0380-8

Hoffman AL, Makowka L, Cramer DV et al (1989) Induction of stable chimerism and elimination of graft-versus-host disease by depletion of $\mathrm{T}$ lymphocytes from bone marrow using immunomagnetic beads. Surgery 106:354-363

Ibrahim Z, Cooney DS, Shores JT et al (2013) A modified heterotopic swine hind limb transplant model for translational vascularized composite allotransplantation (VCA) research. J vis Exp 14:50475. https://doi.org/10.3791/50475

Janssens W, Carlier V, Wu B et al (2003) CD4+CD25+ T cells lyse antigen-presenting $\mathrm{B}$ cells by Fas-Fas ligand interaction in an epitope-specific manner. J Immunol 171:4604-4612

Kanamoto A, Maki T (2004) Chimeric donor cells play an active role in both induction and maintenance phases of transplantation tolerance induced by mixed chimerism. J Immunol 172:1444-1448

Kanitakis J (2008) The challenge of dermatopathological diagnosis of composite tissue allograft rejection: a review. J Cutan Pathol 35:738-744

Kashiwagi N, Porter KA, Penn I et al (1969) Studies of homograft sex and of gamma globulin phenotypes after orthotopic homotransplantation of the human liver. Surg Forum 20:374-376

Kiyomoto T, Toyokawa H, Nakao A et al (2006) The difficulty of eliminating donor leukocyte microchimerism in rat recipients bearing established organ allografts. Transplantation 81:438-444. https:// doi.org/10.1097/01.tp.0000188948.72706.4d

Klimczak A, Agaoglu G, Carnevale K, a, et al (2006) Applications of bilateral vascularized femoral bone marrow transplantation for chimerism induction across the major histocompatibility (MHC) barrier: part II. Ann Plast Surg 57:422-430. https://doi.org/10. 1097/01.sap.0000227049.65952.26

Klimczak A, Unal S, Jankowska A et al (2007) Donor-origin cell engraftment after intraosseous or intravenous bone marrow transplantation in a rat model. Bone Marrow Transplant 40:373-380. https://doi.org/10.1038/sj.bmt.1705743

Krajewska M, Weyde W, Klinger M (2006) Immune tolerance after renal transplantation. Postepy Hig Med Dosw 60:163-169

Lee KM, Stott RT, Zhao G et al (2014) TGF- $\beta$-producing regulatory B cells induce regulatory $\mathrm{T}$ cells and promote transplantation tolerance. Eur J Immunol 44:1728-1736. https://doi.org/10.1002/eji. 201344062

Leonard DA, McGrouther DA, Kurtz JM et al (2012) Tolerance induction strategies in vascularized composite allotransplantation: mixed chimerism and novel developments. Clin Dev Immunol 2012:863264. https://doi.org/10.1155/2012/863264

Leonard DA, Cetrulo CL, McGrouther DA et al (2013a) Induction of tolerance of vascularized composite allografts. Transplantation 95:403-409. https://doi.org/10.1097/TP.0b013e31826d886d

Leonard DA, Kurtz JM, Cetrulo CL (2013b) Vascularized composite allotransplantation: towards tolerance and the importance of skinspecific immunobiology. Curr Opin Organ Transplant 18:645651. https://doi.org/10.1097/MOT.0000000000000022

Lin CH, Anggelia MR, Cheng HY et al (2021) The intragraft vascularized bone marrow component plays a critical role in tolerance induction after reconstructive transplantation. Cell Mol Immunol 18:363-373. https://doi.org/10.1038/s41423-019-0325-y

Liu X, Shen S, Manser T (2009) Influence of B cell antigen receptor expression level on pathways of B cell tolerance induction. $\mathrm{J}$ Immunol 182:398-407
Louveau A, Harris TH, Kipnis J (2015) Revisiting the mechanisms of CNS immune privilege. Trends Immunol 36:569-577. https://doi. org/10.1016/j.it.2015.08.006

McPherson C (1980) Regulation of animal care and research? NIH's opinion. J Anim Sci 51:492-496

Morelon E, Kanitakis J, Petruzzo P (2012) Immunological issues in clinical composite tissue allotransplantation: where do we stand today? Transplantation 93:855-859. https://doi.org/10.1097/TP. 0b013e31824728b8

Muldoon LL, Alvarez JI, Begley DJ et al (2013) Immunologic privilege in the central nervous system and the blood-brain barrier. J Cereb Blood Flow Metab 33:13-21. https://doi.org/10.1038/ jcbfm.2012.153

Murase N, Demetris AJ, Matsuzaki T et al (1991) Long survival in rats after multivisceral versus isolated small-bowel allotransplantation under FK 506. Surgery 110:87-98

Nasir S, Bozkurt M, Klimczak A et al (2008) Large antigenic skin load in total abdominal wall transplants permits chimerism induction. Ann Plast Surg 61:572-579. https://doi.org/10.1097/SAP.0b013 e31816d8275

Nasir S, Klimczak A, Sonmez E et al (2010) New composite tissue allograft model of vascularized bone marrow transplant: the iliac osteomyocutaneous flap. Transpl Int 23:90-100. https://doi.org/ 10.1111/j.1432-2277.2009.00944.x

Nikolic B, Onoe T, Takeuchi Y et al (2010) Distinct requirements for achievement of allotolerance versus reversal of autoimmunity via nonmyeloablative mixed chimerism induction in NOD mice. Transplantation 89:23-32. https://doi.org/10.1097/TP.0b013e3181 c4692e

Nishihara H, Soldati S, Mossu A et al (2020) Human CD4+ T cell subsets differ in their abilities to cross endothelial and epithelial brain barriers in vitro. Fluids Barriers CNS 17:3. https://doi.org/ 10.1186/s12987-019-0165-2

Oh BC, Furtmüller GJ, Fryer ML et al (2020) Vascularized composite allotransplantation combined with costimulation blockade induces mixed chimerism and reveals intrinsic tolerogenic potential. JCI Insight 5:e128560. https://doi.org/10.1172/jci.insight.128560

Paiva RS, Lino AC, Bergman ML et al (2013) Recent thymic emigrants are the preferential precursors of regulatory $\mathrm{T}$ cells differentiated in the periphery. Proc Natl Acad Sci USA 110:6494-6499. https:// doi.org/10.1073/pnas.1221955110

Parsons RF, Vivek K, Redfield RR et al (2009) B-cell tolerance in transplantation: is repertoire remodeling the answer? Expert Rev Clin Immunol 5:703. https://doi.org/10.1586/eci.09.63

Petit F, Minns AB, Dubernard JM et al (2003) Composite tissue allotransplantation and reconstructive surgery: first clinical applications. Ann Surg 237:19-25. https://doi.org/10.1097/01.SLA. 0000041228.23111 .30

Pilat N, Baranyi U, Klaus C et al (2010) Treg-therapy allows mixed chimerism and transplantation tolerance without cytoreductive conditioning. Am J Transplant 10:751-762

Rahhal DN, Xu H, Huang WC et al (2009) Dissociation between peripheral blood chimerism and tolerance to hindlimb composite tissue transplants: preferential localization of chimerism in donor bone. Transplantation 88:773-781. https://doi.org/10.1097/TP. 0b013e3181b47cfa

Robertson N, Fairchild P, Waldmann H (2007) Ectopic transplantation of tissues under the kidney capsule. Methods Mol Biol 380:347-353

Safinia N, Leech J, Hernandez-Fuentes M et al (2013) Promoting transplantation tolerance; adoptive regulatory T cell therapy. Clin Exp Immunol 172:158-168. https://doi.org/10.1111/cei.12052

Sakaguchi S, Yamaguchi T, Nomura T et al (2008) Regulatory T cells and immune tolerance. Cell 133:775-787. https://doi.org/10. 1016/j.cell.2008.05.009 
Schlatt S, Rosiepen G, Weinbauer GF et al (1999) Germ cell transfer into rat, bovine, monkey and human testes. Hum Reprod 14:144-150

Schnider JT, Weinstock M, Plock JA et al (2013) Site-specific immunosuppression in vascularized composite allotransplantation: prospects and potential. Clin Dev Immunol 2013:495212. https://doi. org/10.1155/2013/495212

Shevach EM (2006) From vanilla to 28 flavors: multiple varieties of T regulatory cells. Immunity 25:195-201. https://doi.org/10.1016/j. immuni.2006.08.003

Siemionow M (2017) The decade of face transplant outcomes. J Mater Sci Mater Med 28:1-4. https://doi.org/10.1007/ s10856-017-5873-z

Siemionow M (2020) The past the present and the future of face transplantation. Curr Opin Organ Transplant 25:568-575. https://doi. org/10.1097/MOT.0000000000000812

Siemionow M, Klimczak A (2009) Immunodepletive anti-alpha/betaTCR antibody in transplantation of composite tissue allografts: Cleveland clinic research experience. Immunotherapy 1:585-598. https://doi.org/10.2217/imt.09.34

Siemionow M, Klimczak A (2010) Advances in the development of experimental composite tissue transplantation models. Transpl Int 23:2-13. https://doi.org/10.1111/j.1432-2277.2009.00948.x

Siemionow M, Klimczak A (2013) Chimerism-based experimental models for tolerance induction in vascularized composite allografts: Cleveland clinic research experience. Clin Dev Immunol 2013:831410. https://doi.org/10.1155/2013/831410

Siemionow M, Kulahci Y (2007) Experimental models of composite tissue allograft transplants. Semin Plast Surg 21:205-212. https:// doi.org/10.1055/s-2007-991190

Siemionow M, Nasir S (2007) Chimerism and bone marrow based therapies in transplantation. Microsurgery 27:510-521. https:// doi.org/10.1002/micr.20395

Siemionow M, Nasir S (2008) Impact of donor bone marrow on survival of composite tissue allografts. Ann Plast Surg 60:455-462. https://doi.org/10.1097/SAP.0b013e3180db2765

Siemionow M, Oke R, Ozer K et al (2002) Induction of donor-specific tolerance in rat hind-limb allografts under antilymphocyte serum and cyclosporine A protocol. J Hand Surg Am 27:1095-1103. https://doi.org/10.1053/jhsu.2002.36524

Siemionow MZ, Izycki DM, Zielinski M (2003) Donor-specific tolerance in fully major histocompatibility major histocompatibility complex-mismatched limb allograft transplants under an antialphabeta $\mathrm{T}$ cell receptor monoclonal antibody and cyclosporine A protocol. Transplantation 76:1662-1668. https://doi.org/10. 1097/01.TP.0000105343.49626.6P

Siemionow M, Ozer K, Izycki D et al (2005a) A new method of bone marrow transplantation leads to extension of skin allograft survival. Transplant Proc 37:2309-2314. https://doi.org/10.1016/j. transproceed.2005.03.054

Siemionow MZ, Demir Y, Sari A et al (2005b) Facial tissue allograft transplantation. Transplant Proc 37:201-204. https://doi.org/10. 1016/j.transproceed.2004.12.055
Siemionow MZ, Klimczak A, Unal S (2005c) Different routes of donorderived hematopoietic stem cell transplantation for donor-specific chimerism induction across MHC barrier. Transplant Proc 37:6264. https://doi.org/10.1016/j.transproceed.2004.12.216

Siemionow M, Klimczak A, Unal S et al (2008) Hematopoietic stem cell engraftment and seeding permits multi-lymphoid chimerism in vascularized bone marrow transplants. Am J Transplant 8:1163-1176. https://doi.org/10.1111/j.1600-6143.2008.02241.x

Siemionow M, Madajka M, Cwykiel J (2012) Application of cell-based therapies in facial transplantation. Ann Plast Surg 69:575-579. https://doi.org/10.1097/SAP.0b013e31824803a5

Singh AK, Seavey CN, Horvath KA et al (2012) Ex-vivo expanded baboon CD4+ CD25 Hi Treg cells suppress baboon anti-pig T and B cell immune response. Xenotransplantation 19:102-111. https://doi.org/10.1111/j.1399-3089.2012.00697.x

Starzl TE (1971) Transplantation of whole human organs. Proc Am Philos Soc 115:258-266

Stevenson PG, Bangham CR, Hawke S (1997) Recruitment, activation and proliferation of CD8+ memory T cells in an immunoprivileged site. Eur J Immunol 27:3259-3268. https://doi.org/10.1002/ eji. 1830271225

Strazielle N, Creidy R, Malcus C et al (2016) T lymphocytes traffic into the brain across the blood-CSF barrier: evidence using a reconstituted choroid plexus epithelium. PLoS ONE 11:e0150945. https:// doi.org/10.1371/journal.pone.0150945

Tario JD, Gray BD, Wallace SS et al (2007) Novel lipophilic tracking dyes for monitoring cell proliferation. Immunol Invest 36:861-885

Toledo-Pereyra LH, Bandlien KO, Gordon DA et al (1984) Renal subcapsular islet cell transplantation. Diabetes 33:910-914

Walch JM, Lakkis FG (2014) T-cell migration to vascularized organ allografts. Curr Opin Organ Transplant 19:28-32

$\mathrm{Xu} \mathrm{H}$, Ramsey DM, Wu S et al (2013) Simultaneous bone marrow and composite tissue transplantation in rats treated with nonmyeloablative conditioning promotes tolerance. Transplantation 95:301308. https://doi.org/10.1097/TP.0b013e31827899fc

Yang JH, Eun SC (2017) Therapeutic application of T regulatory cells in composite tissue allotransplantation. J Transl Med 15:218. https://doi.org/10.1186/s12967-017-1322-5

Yazici I, Carnevale K, Klimczak A et al (2007) A new rat model of maxilla allotransplantation. Ann Plast Surg 58:338-344. https:// doi.org/10.1097/01.sap.0000237683.72676.12

Zhu B, Luo L, Chen Y et al (2002) Intrathecal Fas ligand infusion strengthens immunoprivilege of central nervous system and suppresses experimental autoimmune encephalomyelitis. J Immunol 169:1561-1569

Publisher's Note Springer Nature remains neutral with regard to jurisdictional claims in published maps and institutional affiliations. 